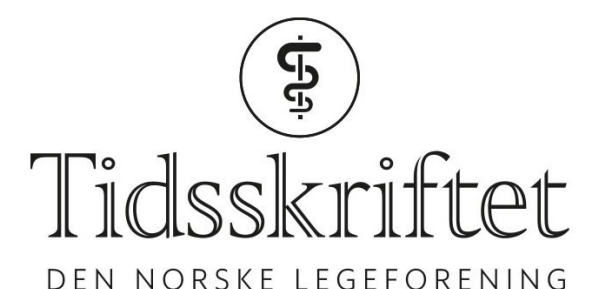

DEN NORSKE LEGEFORENING

\title{
Kosmetisk kirurgi er medisin
}

KOMMENTAR

\section{JARL ARVID BUNAES}

E-post: jbunaes@online.no

Jarl Arvid Bunæs er ørenesehalsspesialist og ansiktskirurg ved Bærum Plastikkirurgi og Øre-nese-hals. Ingen oppgitte interessekonflikter.

Kosmetisk kirurgi er en subspesialitet som utføres av plastikkirurger, øre-nese-halsleger og i mindre grad andre kirurgiske spesialiteter. Denne type kirurgi står ikke høyt i kurs hos fastlegene Henrik Vogt og Andreas Pahle (1). De spør om en kosmetisk kirurg i det hele tatt kan bli regnet som lege. Jeg mener ja.

En stor del av den estetiske kirurgi er også rekonstruktiv, for eksempel leppeganeoperasjoner, utstående ører, korreksjoner etter traumer, arrkorreksjoner for eksempel som følge av acne, funksjonell- og kosmetisk nesekirurgi, ansiktsløft, øyelokkskirurgi.

Dagens skjønnhetsbegrep er ikke skapt av kosmetiske kirurger. Skjønnhetsbegrepene har eksistert til alle tider, lenge før kosmetiske kirurger så dagens lys. Ved vår klinikk har vi løpende evalueringer av operasjonens innvirkning på livskvalitet. Nesten samtlige er fornøyd.

Jeg tror Vogt og Pahle mangler kunnskap om vår arbeidshverdag og arbeidsmetoder. Korreksjon av utstående ører har vært utført ved norske sykehus i en mannsalder. Bør henvisning til psykolog være alternativet der et barn mobbes for utstående ører?

Hva er forskjellen på å korrigere utstående ører og en spesiell neseform, manglende hake eller dobbelthake, tunge øyelokk, acnearr? Hvordan kan man utøve god medisin når en pasient henvises for mobbing, kanskje på grunn av alvorlige depressive symptomer, og har sluttet på skolen på grunn av mobbing for eksempel for svært spesielle neser?

De aller fleste som kommer til oss kommer ikke for å bli vakre. De vil se «normale» ut.

LITTERATUR:

1. Vogt H, Pahle A. Legeprofesjonens (kosm)etiske problem. Tidsskr Nor Legeforen 2018; 138. doi: 10.4045/tidsskr.18.0607. [PubMed][CrossRef]

Publisert:30. oktober 2018. Tidsskr Nor Legeforen. DOI: 10.4045/tidsskr.18.0781

(C) Tidsskrift for Den norske legeforening 2020. Lastet ned fra tidsskriftet.no 